TITLE:

\title{
TWO NEW SPECIES OF THE GENUS EUBRANCHUS FROM JAPAN (NUDIBRANCHIA-EOLIDACEA)
}

AUTHOR(S):

Baba, Kikutaro

CITATION:

Baba, Kikutaro. TWO NEW SPECIES OF THE GENUS EUBRANCHUS FROM JAPAN (NUDIBRANCHIA-EOLIDACEA). PUBLICATIONS OF THE SETO MARINE BIOLOGICAL LABORATORY 1960, 8(2): 299-302

ISSUE DATE:

1960-12-20

URL:

http://hdl.handle.net/2433/174650

RIGHT: 


\title{
TWO NEW SPECIES OF THE GENUS EUBRANCHUS FROM JAPAN (NUDIBRANCHIA-EOLIDACEA)
}

\author{
KIKUTARÓ BABA \\ Biological Laboratory, Osaka Gakugei University \\ With Plate XXXIV
}

The acleioproctic family Eubranchidae consists of six genera: Eubranchus Forbes, 1838 (=Amphorina Quatrefages, 1844 ; Galvina Alder \& Hancock, 1855); Capellinia TrINCheSe, 18741); Galvinella ElIOT, 1907 ; Eubranchopsis BABA, 1949 ; Egalvina OdHNer, 1929; and Cumanotus ODHNER, 1907.

In the genus Eubranchus the anus is dorso-lateral in the interhepatic space, the gills are arranged in simple oblique rows on each side, the jaw-edge is armed with a row of denticles, and the lateral teeth of the triseriate radula are platelike without denticulations.

Unfortunately the classification of the genus is varied according to different authors (see Eliot, 1910, pp. 169-170; Iredale and O'DonOGHUE, 1923, pp. 208209; O'Donoghue, 1929, pp. 749-750; Odhner, 1939, pp. 66-67; LемсHE, 1935, p. 146, 1941, pp. 36-37; Pruvot-Fol, 1951, p. 66; Marcus, 1958, pp. 44-45, 1959, p. 74). The following is a tentative enumeration of the valid (or probably valid) species of Eubranchus so far known from the world: 1. E. tricolor ForBes, 1838, from the Atlantic and the Mediterranean; 2. E. exiguus (Alder \& Hancock, 1848), from the Atl. and the Med.; 3. E. pallidus (A. \& H., 1842), from the Atl. and the Med.; 4. E. cingulatus (A. \& H., 1847) =? E. vittatus (A. \& H., 1842), from the Atl. and the Med.; 5. E. rupium (Möller, 1842), from the Atl.; 6. E. flavus (Trinchese, 1879), from the Med.; 7. E. adarensis OdHNER, 1934, from the Antarctic; 8. E. fuegiensis OdHner, 1926, from Tierra del Fuego; 9. E. agrius MARcus, 1959, from Chile; 10. E. productus (FARRAN, 1905), from the Gulf of Mannar; and 11. ? E. montraveli RISBEC, 1937, from New Caledonia.

The present paper includes the description of two new species of Eubranchus from Japan.

1) Capellinia is included within Eubranchus by PRuvot-FoL, 1951, p. 66 (as a subgenus Capellinia); it is considered separate from Eubranchus by MARCUS, 1958, pp. 41-44.

Publ. Seto Mar. Biol. Lab., VIII (2), 1960. (Article 21) 


\section{Eubranchus horii $\mathrm{BABA}$, n. sp.

\author{
Hori-minoumiushi (n. n.) \\ (P1. XXXIV, Figs. 1A-1E)
}

This is one of the typically organized species of the genus Eubranchus. Total length $5 \mathrm{~mm}$. Head with cephalic tentacles and rhinophores, the latter simple. Foot-corners rounded. Branchial papillae long, fusiform, smooth. They are arranged in (7-8) oblique rows on each side, about $2-3$ in the 1 st, 3 in the $2 \mathrm{nd}, 4$ in the 3 rd, 2-3 in the 4 th and 5 th, and 1-2 in the succeeding rows; the foremost 3 rows (the right liver and the left partner) rather close together, and these are moderately separated from the posterior liver rows. Anus in the interhepatic space, just in front of the inner corner of the right post-anal row. Nephroproct (?). Genital orifice below the middle of the anterior liver rows. Colouring unmistakable in Eubranchus. General ground-colour of body yellowish white; cephalic tentacles and rhinophores always combined by a longitudinal brown band which runs along the edge of the head; there is always a short longitudinal marking of brown on the median line of the back, at about the level of the anterior liver rows. Cephalic tentacles and rhinophores banded each with brown in the middle of their length. Branchial papillae with a dark brown liver-vein and a subapical brown ring. Sole colourless. A single row of about 12 denticles on the jaw-edge. Radula formula $35 \times 1.1 .1$; central tooth with a median cusp and about 3 denticles on each side of it; lateral teeth moderately broad, plate-like.

Loc.: Hayama, Sagmi Bay, in shallow water (Apr. 1951, 2 sps., coll. by the Biological Laboratory, Imperial Household).

Additional localities of this species are: Tannowa, Osaka Bay, on shore (Mar. 1959, 2 sps., coll. by Mr. Hamatani); Mukaishima, Inland Sea of Seto, from among the hydroid colony on Ecklonia leaves (May 1958, many sps., coll. by Dr. INABA) ; Abugashima, Toyama Bay, on shore (Apr. 1951, 1 sp., coll. by Mr. ABE). All the specimens in these collections agree with the type from Sagami Bay, both in shape and colours of the body. They measure from 3 to $7 \mathrm{~mm}$ in length.

This species has been named after Dr. Kenzo HorI, a gentleman greatly interested in the extension of the nudibranch survey in Toyama Bay and the vicinities.

\section{Eubranchus misakiensis BABA, n. sp.}

Misaki-hime-minoumiushi (n. n.)

(Pl. XXXIV, Figs. 2A-2G)

Body about $5 \mathrm{~mm}$ in length. Rhinophores simple. Foot-corners produced in short horns as in E. productus (FARRAN, 1905). Branchial papillae long, fusiform, 
are arranged in 6 oblique rows on each side, about 4 in the 1st, 5 in the 2 nd, 4 in the $3 \mathrm{rd}, 3$ in the 4 th, $2-1$ in the following rows; the foremost 2 rows (the right and the left livers) rather close together, and these are separated from the posterior liver rows. Anus just in front of the inner corner of the right postanal row. Genital orifice between and below the right anterior liver rows. General ground-colour yellowish white; it is scattered with chocolate-brown spots everywhere on body, on cephalic tentacles and rhinophores, and on gills. Sole colourless. Each of the branchial papillae with a yellow subapical ring and a bluish green liver-vein. Jaw-edge provided with about 15 denticles in a single row. Radula formula $40 \times 1.1 .1$. Central tooth with 3-4 denticles on each side of the median cusp; lateral teeth very broad, plate-like.

Loc.: Misaki, Sagami Bay, on Obelia colony (Nov. 1956, 3 sps., coll. by the Biological Laboratory, Imperial Household).

A fairly large number of the specimens of this species were collected by Dr. INABA from Mukaishima, Inland Sea of Seto in May 1958 and in March 1960, from among the Sargassum weeds. The length of the animal is $3-5 \mathrm{~mm}$. The body-colours are generally as in the Sagami specimens: yellowish white groundcolour covered thickly with chocolate-brown spots; a chocolate-brown ring in the middle of the cephalic tentacles; 2-3 rings of the same colour on the length of the rhinophores; a chocolate-brown ring down the tip of each of the branchial papillae. The foot-corners are angulate. It is especially marked that the livervein within each of the branchial papillae develops a large boss in the middle of its length. The integument of the papillae is naturally elevated above the boss, but not studded with knobs like in Capellinia. Nephroproct closely in front of anus. Jaw-edge with about 16 denticles in a row. Radula formula $50 \times 1.1 .1$, central tooth with 4-5 denticles on each side, lateral teeth broad, plate-like.

The present new species appears to be especially characterized by the colours, by the angulate foot-corners and by the branchial papillae with a boss in the middle of the liver-veins.

Acknowledgements: It is my duty to thank the following gentlemen who have placed their collections at my disposal for examination: Dr. Hirotaro HatTori (Biological Laboratory of the Imperial Household) ; Mr. Iwao Hamatani (Sennan Senior High School of Osaka Pref.); Dr. Akihiko INABa (Mukaishima Marine Biological Laboratory of the Hiroshima University); and Mr. Takeo ABE (Takaoka Senior High School of Toyama Pref.).

\section{REFERENCES}

Alder, J. \& HANCOCK, A. 1845-55. A monograph of the British nudibranchiate Mollusca. Pts. 1-7.

BABA, K. 1949. Opisthobranchia of Sagami Bay. Iwanami Shoten, Tokyo.

Eliot, C. 1910. A monograph of the British nudibranchiate Mollusca. Pt. 8 (Suppl.). 
Farran, G. P. 1905. Report on the opisthobranchiate Mollusca. Rep. Pearl Oyster Fish. Gulf of Manaar. Suppl. Rep. Rep. Mar. Biol. Ceylon, pt. 3.

Iredale, T. \& O'Donoghue, C. H. 1923. List of British nudibranchiate Mollusca. Proc. Mal. Soc. London, vol. 15, pts. 4-5.

LEMCHE, H. 1935. On some nudibranchiate gastropods from the northern Atlantic. Vidensk. Medd. fra Dansk naturh. Foren., Bd. 99.

land, Bd. 80 , no. 7 .

MARCUS, E. 1958. On western Atlantic opisthobranchiate gastropods. Amer. Mus. Novitates, no. 1906.

1959. Lamellariacea und Opisthobranchia. Reports of the Lund University Chile Expedition 1948-49. Lunds Univ. Arsskr., N. F., Avd. 2, Bd. 55, no. 9.

O'Donoghue, C. H. 1929. Report on the Opisthobranchiata. Results of the Cambridge Expedition to the Suez Canal, 1924. Trans. Zool. Soc. London, vol. 22, pt. 6.

ODNER, N. 1939. Opisthobranchiate Mollusca from the western and northern coasts of Norway. Kgl. Norske Vidensk. Selskab. Skr., no. 1.

Pruvot-Fol, A. 1951. Étude des nudibranches de la Méditerranée. Arch. Zool, exp. et gén., tom. 88 , fasc. 1 .

\section{EXPLANATION OF PLATE XXXIV}

Figs. 1A-1E. Eubranchus horii. 1A. Animal from Hayama, Sagami Bay (Apr. 24, 1951, length $5 \mathrm{~mm}$ ) ; 1B. Right side of the same animal, a. anus, b. genital orifice; 1 C. Jaw-edge $(\times 400)$; 1D. A half-row of radula $(\times 690)$, a. central tooth, b. lateral tooth; 1 E. Animal from Tannowa, Osaka Bay (Mar. 28, 1959, length $6 \mathrm{~mm}$ ).

Figs. 2A-2G. Eubranchus misakiensis. 2A. Animal from Misaki, Sagami Bay (Nov. 27, 1956, length $5 \mathrm{~mm}$, original fig. taken by the Biological Laboratory, Imperial Household); 2B. Right side of the same animal, a. anus, b. genital orifice; $2 \mathrm{C}$. A jaw-plate $(\times 45)$; 2D. Jaw-edge $(\times 400)$; 2E. A half-row of radula $(\times 430)$, a. central tooth, b. lateral tooth; $2 \mathrm{~F}$. Animal from Mukaishima, Inland Sea of Seto (Mar. 12, 1960, length $3 \mathrm{~mm}$ ); 2G. Longitudinal section of a branchial papilla, showing a boss in the middle of the liver-vein. 
Publ. Seto Mar. Biol. Lab., VIII, 2 (1960)
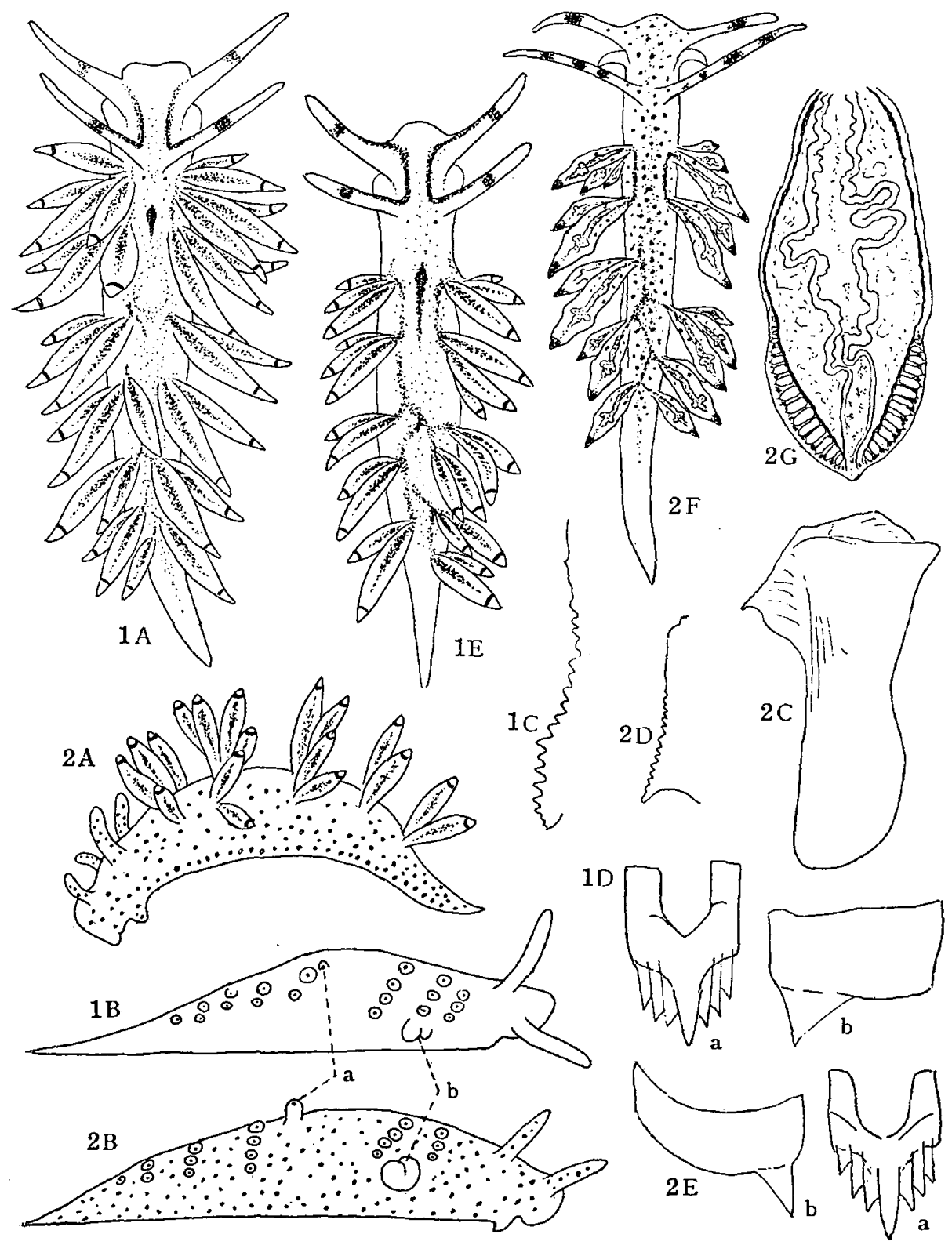

K. Baba: Two New Species of the Genus Eubranchus from Japan. 